\title{
Är lönebidragsanställningar en demokratisering av museer?
}

\author{
CeCILIA RodÉHN*
}

Title: Do wage subsidies help make museums more democratic?

Abstract: This paper investigates whether the labour market measure known as wage subsidies, coupled with lifelong learning, contributes to a more democratic museum. The paper begins with an investigation of the historical and political implications of wage subsidies at the Jamtli county museum in Östersund, Sweden. The paper continues by exploring whether lifelong learning and learning at the workplace contribute to further learning and rehabilitation of the persons employed via such labour market measures. The paper concludes with a discussion of whether lifelong learning and labour market measures can contribute to further preservation and mediation of cultural heritage and, furthermore, whether if they can make museums more democratic and accessible. The research was carried out at Jamtli during the spring of 2010, and is based on qualitative interviews and archival studies in the museum in question.

Key words: Wage subsidies, Swedish cultural politics, lifelong learning, disabled, democracy.

I över 70 år har den svenska kulturarvssektorn varit beroende av anställda med olika typer av funktionsnedsättning. Vore det inte för dessa personer, anställda i arbetsmarknadsåtgärder som t.ex. lönebidrag, skulle många museer bli tvungna att minska stora delar av sin verksamhet. De lönebidragsanställdas position inom museet varierar från museum till museum. På Länsmuseet Jamtli (tidigare Jämtlands läns museum, härefter Jamtli) återfinns de på museets alla avdelningar och innehar varierande ansvarsposter, dock innehar ingen en chefspost. Arbetsmarknadsåtgärder, som lönebidrag, är kostnadseffektiva för museerna, men åtgärden är också en demokratisk åtgärd, eftersom den hjälper individer till en bättre tillvaro. Arbetsmarknadsåtgärder har utgjort en viktig del i framförallt länsmuseernas kulturpolitiska historia och har stått i centrum för debatter i årtionden. Ämnet är återigen aktuellt då regeringen 2011 beslutade om en stor satsning på lönebidragsanställningar genom det s.k. Kulturarvslyftet (2012-2014). Satsningen syftar till att ge en meningsfull sysselsättning till dem som står långt ifrån arbetsmarknaden och samtidigt bygga upp kunskap, vårda och tillgängligöra kulturarvet. Trots lönebidragsanställdas ständiga aktualitet har det 
76 gjorts få undersökningar och det finns ett behov av att fördjupa sig i ämnet.

Syftet med artikeln är att studera om lönebidragsanställningar sammankopplat med Livslångt Lärande kan vara ett sätt att demokratisera kulturarvet. Således gavs jag 2010 möjligheten av Nordiskt Centrum för Kulturarvspedagogik (NCK) att under fyra månader undersöka Livslångt Lärande och lönebidragsanställda vid Jamtli och Landsarkivet i Östersund (den senare kommer inte behandlas i den här texten, se istället Rodéhn 2010, 2011). Livslångt Lärande är en teoretisk term, som avser alla former av lärande från vaggan till graven och där den personliga processen och individuella utvecklingen betonas, men det är också ett politiskt begrepp som är inkorporerat i EU:s ekonomiska politik. Detta kommer att förklaras mer ingående senare i artikeln. Det blev tydligt genom studien att ledningen vid Jamtli är väl insatt i Livslångt Lärandes politiska och teoretiska begrepp, men att mina informanter inte var det. Livslångt Lärande uppfattades av informanterna som någonting som bidrog till att finansiera institutionen med EU-medel, inte att det utgjorde en agenda med syfte att genomsyra klimatet på arbetsplatsen. På så vis döljs de politiska aspekterna vilket får implikationer för demokratiseringen av kulturarvet. Demokratisering av museer och kulturarv är ett komplext begrepp men kan förenklat förklaras som att representera samhällets mångfald och förbisedda grupper och göra det på ett jämlikt sätt. Det handlar också om att skapa delaktighet i kulturarvet samt att få folk att känna sig välkomna vid institutionerna (Galla 2003, Simpson 2006). Demokratibegreppet inom kulturarvssektorn är dock mångtydigt och ofta inlindat i både dåtida och nutida diskurser som samtidigt avfärdas och bejakas av poli- tiker, akademiker och museitjänstemän (Reddy 2007, Rodéhn 2008). Med andra ord: vad man väljer att definiera som ett demokratiskt museum hör samman med samhällets normativa politiska och socioekonomiska uppfattningar och hur dessa förhåller sig till tidigare diskurser.

\section{BAKGRUND OCH MATERIAL}

Museer och andra kulturarvsinstitutioner har sedan länge sysselsatt personer som inte kunnat skaffa annat arbete på grund av ålder, fysiskt eller psykiskt handikapp. Vissa institutioner har haft så många som 50 procent av personalstyrkan anställd i arbetsmarknadsåtgärder (Rodéhn 2010). Detta har föga uppmärksammats i museologisk litteratur. Därtill råder det brist på texter om funktionsnedsattas situation på museer även om diskussioner har förts av t.ex. Sivesind (1981) som behandlar museer och rehabilitering av människor som lider av stress. Sandell \& Dodd (2010) berör personer med funktionsnedsättning, utställningar och samlingar; Cox (1990) berör utställningar och Rix (2005) diskuterar tillgänglighet. Vad som inte diskuterats är anställda med funktionsnedsättning, och en vidare diskussion skulle därför gynna kunskapen om det svenska museiväsendets organisation och sätt att fungera.

För att förstå de arbetshandikappades möjlighet till lärande är undersökningen en etnografisk studie baserad på kvalitativa semistrukturerade intervjuer samt arkivstudier av olika typer av dokument. Kvalitativ metod är en viktigt redskap för att förstå det etnografiska fältets komplexitet. Metoden används för att förstå hur informanterna organiserar och upplever den verklighet de befinner sig i (Denzing \& Lincoln 2000: 10). Målet med under- 
sökningen var att intervjua alla lönebidragsanställda vid Jamtli för att få en tydlig bild av möjligheten till lärande på arbetsplatsen. Eftersom frågan om vilken anställningsform de innehade var känslig distribuerade personalchefen ett brev från mig till de anställda, som själva fick ta kontakt om de önskade medverka i undersökningen. De informanter som valde att delta förde jag en timmes diskussion med, vilken spelades in. Materialet analyserades i relation till hur de talade om lärande, arbetsplatsen och arbetshandikapp. Alla informanter har blivit kodade för att skydda deras identitet.

Det visade sig att av 32 lönebidragsanställda svarade endast fem personer trots påminnelser. Att det blev så få bekräftar den sociala sårbarheten bland lönebidragsanställda som Leymann (1992) och Holmqvist (2006) har belyst. Det fanns en ovilja att avslöja sin anställningsform på grund av en nedsättande syn på lönebidragsanställda som andra klassens personal. Det etnografiska materialet visade att ledningen var medveten om detta men betonade att den inte gjorde någon skillnad mellan de anställda. Mina informanter upplevde trots allt en skillnad, även om de poängterade att de i praktiken inte blev behandlade annorlunda. De fem personer som valde att delta i studien ger långt ifrån en fullständig bild av lönebidragsanställda vid institutionen, men de påvisar viktiga tendenser rörande Livslångt Lärande och upplevelsen av att vara anställd med lönebidrag.

Jag intervjuade även museichefen Henrik Zipsane, tidigare museichefen Sten Rentzhog samt Sten Gauffin, förste antikvarie och tidigare biträdande museichef. Brev, policydokument, statliga utredningar, EU-dokument och andra handlingar kopplade till institutionen analyserades. Dokument kan förstås som in- dividens och samhällets intellektuella minne. handlingar, interaktioner och möten. Dokument måste vidare förstås som sociala konstruktioner som är producerade, delade, socialt organiserade och utväxlade som en del i sociala interaktioner (Atkinson \& Coffey 2004: 57, 59). Dokumenten och intervjuerna med ledningen gav en djupare förståelse av de nationella och internationella krav som åligger institutionerna. Intervjuer och dokument analyserades i relation till varandra och till teorier om Livslångt Lärande och annat lärande på arbetsplatsen, vilket kommer att redogöras tydligare för under avsnittet Livslångt Lärande. Genom att ställa intervjuerna i relation till teorier om Livslångt Lärande och till arkivmaterialet, framträder den kontext i vilket lärandet sker och på så sätt kan de politiska och ekonomiska implikationerna för lärandet förstås.

\section{HISTORISK BAKGRUND}

Lönebidrag som anställningsform har en lång historia. Systemet skapades 1934 och var en form av beredskapsarbete som betecknades "arkivarbete". Tituleringen gällde oavsett vilken form av uppgift som utfördes och kom att fortsätta fram till 1970-talet när bidragssystemet bytte form. Arkivarbete utgjorde en del i Sveriges arbetsmarknadspolitik och gick ut på att erbjuda sysselsättning som tillvaratog individens kompetenser (Trygged 1996: 18-21). Systemet var anpassat för män, eftersom de ansågs som familjeförsörjare. Efter andra världskriget ändrades systemet och bidragsformen riktades till flyktingar med en akademisk bakgrund, många av dessa var framstående akademiker och bidrog också med egen forskning. Jamtli berördes av systemet första gången 1945 då det föreslogs att en estnisk 
78 flykting skulle få arkivarbete där (Trygged 1996: 21, 28, Engelbrektsson 1997: 7-9, Rodéhn 2010).

Arkivarbete var reserverat för äldre och personer som hade svårigheter att få en vanlig anställning (SFS 1971: 202). Trots detta anställde institutionerna ofta personer utan funktionsnedsättning men som stod utanför arbetsmarknaden. Sten Rentzhog (2010-03-24) berättade för mig i en intervju att ca 40 procent av museets personal tidigare var lönebidragsanställda. Dessa personer var högt kvalificerade och han betraktade dem som permanent personal. Flertalet av hans anställda var t.ex. frånskilda kvinnor som varit hemmafruar och helt plötsligt blivit tvungna att försörja sig själva men saknade arbetslivserfarenhet. Situationen på Jamtli var därför något annorlunda än på andra platser och Rentzhog jämförde Jamtlis situation med den i storstäderna där arkivarbetarna ofta betraktades som extrapersonal. Jamtli hade därför ett annat arbetsklimat som Rentzhog menade tog tillvara de regionala resurserna. Enligt min uppfattning verkar denna tradition fortfarande efterlevas på Jamtli och i dagsläget har institutionen cirka 30 procent lönebidragsanställda.

1974 skyddades arkivarbetares anställningar i lagen om anställningsskydd och några år senare ersattes arkivarbeten med "lönebidrag". Detta betydde att ansvaret för de anställda flyttades från staten till institutionerna och bidrag gavs för att täcka en del av de anställdas löner (SFS 1974: 13, SFS 1974: 12, Budgetpropositionen 1978/79: 73, Engelbrektsson 1997: 4). Detta betydde att museerna nu stod för delar av kostnaderna. Länsmuseerna protesterade mot denna reform eftersom det påverkade deras ekonomi avsevärt. Rentzhog och Hagberg (1978) skrev i ett brev att de måste uppvakta ministrar för att kunna säkra finansiering och skapa förståelse för museernas situation. Rentzhog (1979) skrev ett år senare att museerna skulle komma att befinna sig i en mycket svår situation och deras aktiviteter begränsas om förslaget gick igenom. Arkivmaterial har visat att museerna blev tvungna att skära ned på antalet anställda, samtidigt som personer med lönebidrag, som var fundamentala för museernas fortsatta existens, inte anställdes alls (Länsmuseernas samarbetsråd 1981). 1984 krävdes dessutom ett dokumenterat handikapp för att bli lönebidragsanställd, trots detta berättade Sten Rentzhog (2010-03-24) och Sten Gauffin (2010-03-25) att de fortsatte att anställa personer under 1980-talet som nödvändigtvis inte hade en funktionsnedsättning.

Systemet var på väg att förändras igen och länsmuseerna försökte säkra finansiering vilket resulterade $\mathrm{i}$ att när frågan diskuterades $\mathrm{i}$ riksdagen så visades museerna också extra hänsyn (Rentzhog 1988). Trots detta instiftades "flexibelt lönebidrag" 1991 och finansiering till löner gavs beroende på ifrågavarande persons grad av funktionsnedsättning, samtidigt ändrades definitionen av arbetshandikappad till att omfatta människor med psykiska, fysiska, sociala eller intellektuella problem eller handikapp (SFS 1991:333). Museisektorn välkomnade inte förändringen och den ansågs få katastrofala konsekvenser och skada Jamtlis verksamhet (Rentzhog 1991, 1997). Länsmuseerna protesterade mot beslutet och initierade en intensiv uppvaktning av ministrarna. En utredning tillsattes där det bestämdes att museisektorn inte skulle påverkas och länsmuseerna lyckades säkra extra finansiering till lönebidrag. På så sätt erkändes det att museerna saknade lämplig finansiering och att lönebidrag var fundamentalt för att länsmuseerna skulle kunna fortsätta vårda och förmedla kul- 
turarvet, och samtidigt skrevs lönebidragsfrågan in som en väsentlig faktor i kulturpolitiken (SOU 1997: 187, 202-204, SOU 2003: 55, Rentzhog 2010-03-24).

Lönebidragsfrågan är i dagsläget komplicerad i och med att kulturrådet från 2010 beslutat att det extra bidraget till länsmuseer för att finansiera löner till lönebidragsanställda nu har inkorporerats i driftsbidraget (Budgetpropositionen 2009/10: 1). Resultatet av denna omfördelning av finansieringen är att de påverkade museerna nu inte nödvändigtvis kommer att fördela pengarna till lönebidrag. I stället kan de finansiera andra områden där medel saknas och som behöver ses över och som kan förstås har omfördelningen både positiva och negativa aspekter. Den hjälp som museerna har gett till människor som av en eller annan anledning har svårt att få arbete kan nu avta. I slutändan kan detta betyda att museerna kommer att behöva minska antalet lönebidragsanställda. Sten Rentzhog (2010-03-24) och hans efterträdare Henrik Zipsane (2010-02-25) medgav att lönebidrag var arbetskraft till ett lägre pris och att institutionen inte skulle fungera utan dem. Zipsane (2010-02-25) nämnde att det var lockande att anställa individer utan funktionsnedsättning, men han föredrar att behålla systemet eftersom han anser att det bidrar till social sammanhållning och regional utveckling. Han menade att om lönebidragssystemet inte existerade fanns det en risk att dessa personer skulle bli isolerade i sina hem. Därför bidrar museet till att dessa personer blir en del i ett socialt sammanhang och tar del i Livslångt Lärande. Jag menar att öppenhet och tillgänglighet är grundläggande för museets roll i samhället, speciellt i glesbefolkade områden och i områden som lider av arbetslöshet eller påverkas negativt av ekonomisk regression. Där kan museer fungera både som institutioner för lärande men också som aktivt göra en skillnad i samhället. Lönebidragssystemet är därför avgörande för att driva Jamtli och kunna hålla öppet för allmänheten. Regeringens satsning Kulturarvslyftet med start 2012 kommer därför att vara en väl emottagen satsning ur Jamtlis synvinkel.

\section{LIVSLANNGT LÄRANDE}

Livslångt Lärande är en viktig del i utvecklingen av Jamtli både på regional, nationell och internationell nivå. Henrik Zipsane (2008) skriver att Livslångt Lärande är en integrerad del i kulturarvsinstitutionen och i en intervju menade han att han använder EU:s definition av termen för att europeisera Jamtli. I arbetsdokumentet för Jamtlis strategiska plan 2011-2014 (Jamtli 2010) står det att Jamtli i alla led följer europeisk policy rörande Livslångt Lärande. Därtill har Livslångt Lärande blivit ett nyckelord i institutionens arbete för att söka finansiering, nätverka och internationalisera museet (Rodéhn 2010).

Livslångt Lärande används i politisk retorik. Från 1960- och 1970-talen gavs begreppet demokratiska implikationer med tyngd på rätten till utbildning, under 1980- och 1990-talen var Livslångt Lärande en strategi för ekonomisk och teknologisk tillväxt (Ellerström 1996: 42, Dehmel 2006). I dagsläget har Livslångt Lärande blivit ett begrepp i diskussioner rörande humankapital och arbetsmarknadsfrågor. I EU-policydokument rörande Livslångt Lärande har begreppet används för att skapa ett hållbart och ekonomiskt växande samhälle. Man vill skapa aktiva och lärande medborgare för att utrota arbetslösheten och göra individer anställningsbara. Dessa aspekter framställs som metoder för att nå ett de- 
80 mokratiskt samhälle (EU 2000, Rodéhn 2010). Även om det i EU-dokumenten finns ett demokratiskt syfte, så skyms detta av de ekonomiska aspekterna där lärande likriktas och medborgarna blir ekonomiskt aktiva men politiskt passiva (Nijhof 2005: 403). Enligt Jarvis (2007: 100), Gustavsson (1996: 48) och Garrick (1999: 219) har tillämpningen lett till att individen har blivit reducerad till en enbart ekonomisk varelse. Men Boud \& Garrick (1999: 5) menar däremot att Livslångt Lärande leder till att utöka känslan av medborgarskap.

Livslångt Lärande kan i mer filosofiska termer definieras som alla former av lärande från vaggan till graven (Gustavsson 1996: 50). Jarvis (2007:1) definierar Livslångt Lärande som en social situation där upplevda fysiska eller psykiska händelser överförs kognitivt, emotionellt eller praktiskt och blir integrerade i och ändrar en persons livsbiografi. Dock har Livslångt Lärande fått starka politiska konnotationer och Jarvis (2007: 123) och Nihjof (2005: 409) går så långt som att kalla det en social rörelse, en kult eller en religion där Livslångt Lärande formuleras som en metod för att nå ett bättre och mer demokratiskt och upplyst samhälle. Eftersom Jamtli och NCK grundar sin verksamhet i Livslångt Lärande-paradigmet var min undersökning en del i NCK:s utökade intresse för arbetsmarknadsperspektiv, men också i Jamtlis intresse för att finna goda argument för att behålla lönebidragssystemet.

Min utgångspunkt i projektet var att undersöka vad mina informanter associerade med Livslångt Lärande för att sedan leda in diskussionen på lärande överlag. I linje med Billette (2004: 314-316) menar jag att lärande är en sociokulturell process där individer validerar värdet av en upplevelse och hur denne kan lära sig av den. Syftet med just denna ingång var att föra vidare samtalet från lärande till dessa personers specifika situation som lönebidragsanställda. Frågan om anställningsform var som nämnts känslig och min önskan var att personerna själva skulle ta upp problematiken och sitt förhållande till lärande samt vad museet bidragit till i deras liv.

För mina informanter var det självklart att någon form av lärande alltid skedde, men det fanns en skillnad; vissa menade att det var meningen att de skulle lära sig något, medan andra menade att de lärde sig något hela livet. Attityden till Livslångt Lärande avslöjade hur de såg på lärande generellt. Flera av mina informanter associerade lärande till formella platser, som t.ex. skolan eller arbetsplatsen och de menade även att lärande hörde till den yngre generationen. Dessa åsikter fanns hos gruppen som menade att det var meningen att de skulle lära sig något. Deras attityd kan kopplas till vad Barnett (1999: 35) skriver, att lärande kan vara olustigt eftersom det ofta kopplas till att vara omogen eller till att inte veta. Andra informanter menade att lärande handlade om personlig utveckling. Den här gruppen visade sig också ha lärt sig nya saker på arbetsplatsen och ville delta i nya läraktiviteter. Personlig utveckling var också den aspekt som ledningen ansåg vara viktigast med Livslångt Lärande. Till skillnad från informanterna associerade ledningen lärande med informella rum och mellanmänskliga relationer. Min informant Alexander (2010-03-19) sa att Livslångt Lärande egentligen inte var så speciellt, utan att det handlade om givande och tagande. Hans definition är nära Jarvis (2007:1) definition av Livslångt Lärande som en social situation där upplevda fysiska eller psykiska händelser överförs kognitivt, emotionellt eller praktiskt och blir integrerad i och ändrar en persons livsbiografi. Det var uppenbart i samtal med mina 
informanter att Livslångt Lärande är mångtydigt och svårdefinierat. Jag instämmer därför med Olivier (1999) när han skriver att Livslångt Lärande måste definieras bättre om det ska kunna användas på ett meningsfullt sätt.

\section{LÄRANDE PÅ ARBETSPLATSEN}

I dessa sammanhang definieras arbetsplatsen som en plats där sociala normer, tillämpningar samt sociokulturella målinriktade anspråk (t.ex. arbetsmarknadspolitik), bestämmer och skapar individens kunskap (Billette 1999). Vid Jamtli kan det överordnade EU-perspektivet, men också museets pedagogiska profil, nämnas som aspekter som påverkar lärandet. Den pedagogiska profilen är främst riktad mot besökarna, men har kommit att starkt påverka arbetsklimatet. Jamtli har sedan 1970 talet utarbetat nya museipedagogiska metoder och 1984 framträdde pedagogiken med "tidsresor". Metoden har kommit att användas för att förmedla aspekter av tid, rum, klass och genus till besökarna (Rodéhn 2010). I dagsläget används den som en resurs i Jamtlis fokus på regional utveckling och social inkludering (Zipsane 2007). Som exempel kan nämnas program tillsammans med Landsarkivet i Östersund, där man försöker motverka arbetslöshet hos unga vuxna och få dem att fortsätta sin utbildning, åstadkomma anställningsbarhet bland invandrargrupper och minnesprojekt bland demenssjuka (Rodéhn 2010). Genom dessa program menar Zipsane att besökare stimuleras till att lära och samtidigt sparar samhället medel genom att använda kulturarvsinstitutionen som resurs (Zipsane 2007). Det finns många sätt att förstå lärande på arbetsplatsen: det är både en ekonomisk resurs och kan ses som personlig utveckling. Mitt etnografiska material visade dock att de flesta av mina informanter kopplade lärande till anställningsbarhet och inte till personlig utveckling, vilket Jamtlis ledning associerade till Livslångt Lärande. Det är intressant att notera att även om Jamtli styrs av en EU-inriktad arbetsmarknadspolitisk syn på Livslångt Lärande, betonade ledningen de mer mjuka värdena av Livslångt Lärande. De demokratiska mål som Jamtlis ledning argumenterar för med Livslångt Lärande är enligt Nijhof (2005: 404, 409, 414) oförenliga med arbetsplatslärande eftersom Nijhof menar att kunskap alltid har distribuerats ojämnt. Han menar att lärande inte kan kopplas till en idé om ett samhälle på lika villkor. Detta visade mitt etnografiska material också tydligt eftersom de som tidigare hade deltagit i lärandeaktiviteter var de som tyckte sig ha lärt sig något nytt vid institutionen. Informanternas bild av lärande var kopplad till ekonomiska aspekter och till de förväntningar som de upplevde att samhället och institutionen hade på dem som lönebidragsanställda. Vidare var informanterna av uppfattningen att institutionen prioriterade teoretisk kunskap och lärande. De informanter som innehade praktiska arbeten målade upp en hierarkisk pyramid mellan de praktiska och teoretiska yrkesutövarna. Institutionens eventuella favorisering av teoretisk kunskap verifieras till viss del av det faktum att Jamtli avsätter 10 procent av de anställdas tid till forskning i ett fritt valt, men underförstått, teoretiskt ämne. Samtidigt framhöll informanterna att teoretiskt lärande inte var det enda sättet att lära, att arbeta i grupp med ett projekt framställdes ofta som ett sätt genom vilket de lärde sig saker. Vidare talade några av mina informanter om utbyte av information $\mathrm{i}$ grupprelaterade arbetsuppgifter men också i mötet med besökare där de upplevde att de lärde sig nya saker. 
I dessa fall var det uppenbart att deras personliga biografi och de kunskaper som de bar med sig hörde till lärprocessen. Detta var något som gavs annat utrymme i praktiska arbeten än i teoretiska processer, men eftersom detta inte uppmuntrades på samma sätt som den teoretiska kunskapen vid museet fick det underordnad betydelse. Informanterna uppfattade också att kunskap var något som gavs till dem, inte att de bidrog till kunskapsspridning. Jag kommer därför till slutsatsen att deras perspektiv och kunskaper skulle kunna kanaliseras bättre. Framförallt är det viktigt att komma ihåg att det inte är enbart lönebidragsanställda som drar nytta av att arbeta inom kulturarvsinstitutionen. Den mångfald som lönebidragsanställda bidrar med, i form av olika kunskaper och livshistorier, utvecklar institutionen. Henrik Zipsane (2010-02-25) menade också att detta ledde till Livslångt Lärande bland alla anställda.

Vad som uppfattades som en plats där lärande skedde, varierade mycket mellan ledning och anställda. Formella platser som skolor eller kurser refererades till av mina informanter, medan ledningen framhöll sociala relationer och informella platser. Men även om formella platser dominerade diskussionen bland mina informanter var det mellanmänskliga relationer som spelade störst roll i deras personliga utveckling. Kafferasten var det tydligaste exemplet på arbetsplatsen där informanterna deltog i lärande. De två dagliga kafferasterna är mer eller mindre institutionaliserade vid Jamtli och de anställda uppmuntras av ledningen att delta. Kafferasterna ansågs av mina informanter som viktiga tillfällen där de kunde träffa människor, lösa problem, få svar på frågor och vara social. För min informant Sara (2010-03-22) var kafferasterna mycket viktiga; hon kom till institutionen med diag- nosen utbränd och målet med hennes arbetsträning var att lära sig ta en paus. Sara berättade att kafferasten gav henne mervärden i livet och att det alltid fanns något nytt och spännande att lära sig av arbetskamraterna. Det var tydligt genom mina intervjuer att den största delen av kunskapsutbytet på arbetsplatsen skedde vid paus från arbetet. Detta uppfattades först inte som lärande av dem eftersom det skedde på en informell plats.

Jamtlis ledning har också förstått vikten av den mellanmänskliga processen vid lärande och deras förståelse innefattar till stora delar informella platser. Det är just i dessa rum som individer kan möta och förhandla multipla förväntningar, delta i konversationer, pröva och förmedla sin kunskap. Men informellt lärande innefattar också en viss grad av ansvarsbefrielse för institutionen. Museet kan hävda att lärande pågår och hänvisa till Livslångt Lärande utan att ta ett vidare ansvar. Men ett museum som arbetar intensivt med lärande måste också ta sitt ansvar och skapa rum för lärande, en bra början är att uppmuntra lärande vid kafferasten, men de måste också aktivt skapa mer kvalitativa vägar.

Det är lärande i samband med mellanmänskliga processer som är den styrka som Jamtli skulle kunna utarbeta program för bland de anställda. Här finns möjligheter att utveckla kulturarvsspecifika rehabiliteringsprogram och ta lärdom av vad Sivesind (1981) argumenterar för, nämligen att kulturarvsinstitutioner är platser som är väl lämpade för att rehabilitera människor som lider av stressrelaterad ohälsa. Mina informanter var av samma mening som Sivesind, de sa att de mådde bättre efter att de börjat arbeta på museet, det var mycket lugnare att arbeta på en kulturarvsinstitution och jämförde med rehabiliteringsarbete $i$ t.ex. trädgårdar. Vissa av dem kunde till och med 
utföra mer arbete efter de börjat arbeta på Jamtli och de menade att arbetet vid museet hade förändrat deras liv (Sara 2010-03-22, William 2010-03-09, Lisa 2010-03-10, Alexander 2010-03-19, Rupert 2010-03-03).

Vad undersökningen har påvisat, trots ett litet material, är att dessa människor mår bättre och att museet har bidragit till att på individplan och på ett större samhälleligt plan göra en skillnad. Museet kan genom anställningar hjälpa dessa människor, samtidigt hjälper de samhället genom att bevara och förmedla kulturarvet på olika sätt. Detta är perspektiv som ledningen har tagit till sig och Henrik Zipsane (2010-02-25) framhöll aspekter av social sammanhållning och ömsesidig respekt när vi diskuterade lönebidragsanställdas roll inom institutionen. Ur samhällsynpunkt menade han att museet som en samhällsinstitution visade att de representerade människor från alla delar av samhället. Vidare ges arbetshandikappade vid Jamtli en chans att leva ett normalt liv och möta kulturella värden, något som har visat sig ha en positiv inverkan på deras liv. Ska man betrakta kulturarvsinstitutioner som platser där man kan rehabilitera människor genom att uppmuntra lärande måste handlingsplaner utarbetas för hur detta ska åstadkommas. Jamtli måste även ta ansvar för att informera arbetstagarna om deras möjligheter samt om politiska och teoretiska perspektiv på Livslångt Lärande. Museet måste på så sätt komma vidare från de politiskt korrekta implikationer som Livslångt Lärande innebär och konkret arbeta för rehabiliteringsaspekter. För tillfället saknar Livslångt Lärande adekvat praktisk förankring vid museet och för att uppnå demokratiska mål genom Livslångt Lärande måste man som ovan nämnts utarbeta klara riktlinjer för hur detta ska realiseras. I dagsläget lämnas Livslångt Lärande som ett fritt flytande begrepp som görs tillämpligt för politisk retorik för att framhålla demokratiska och positiva aspekter, men tyvärr ekar det ganska tomt.

\section{ÄR LÖNEBIDRAG EN DEMOKRATISK ÅTGÄRD?}

I början av texten ställde jag frågan om lönebidrag sammankopplat med Livslångt Lärande kan medverka till att demokratisera museer och jag ska här försöka besvara frågan. Statliga dokument förklarar att kultur är nödvändigt för att uppnå social sammanhållning, ett hållbart samhälle, mångfald och för att möta medborgarnas behov. Vidare stipuleras förmedling, bevarande, användbarhet, och tillgänglighet som mål för att uppnå ett demokratiskt kulturarv (SOU 2009a: 16-19, 234, 2009b: 21,33, 85, 2009c: 81). Jamtli och många andra museer kan inte i dagsläget uppfylla dessa mål utan lönebidragsanställda eftersom sysslor som dokumentation och förmedling utförs till stor del av individer i olika arbetsmarknadsåtgärder. Dessa arbetsområden hotas konstant genom bristande finansiering och genom förändringar i arbetsmarknadsåtgärdernas utformning. Om museer och andra allmännyttiga institutioner ska kunna uppnå de demokratiska mål som staten har stipulerat behövs antingen mer ekonomiska resurser göras tillgängliga eller också måste resurserna utökas för att kunna sysselsätta fler lönebidragsanställda. Lönebidragsanställda ska naturligtvis inte ersätta annan kvalificerad och utbildad personal. Den stora frågan är hur man finner kvalificerad personal bland de arbetshandikappade för att inte kompromissa med kulturarvsproduktionen och inte hämma arbetsmarknaden för museitjänstemän utan arbetshandikapp.

Den internationella museologiska diskus- 
sionen om vad som konstituerar ett demokratiskt museum är präglad av en postkolonial och poststrukturell kritik mot den tidigare museikulturen. Vad som argumenteras för är mer multivokala narrativ och en dekonstruktion av tidigare berättelser. En metod för att uppnå detta är genom lekmannaperspektivet, där gemene mans minnen, upplevelser och berättelser av historien är av lika stor vikt som den professionella museologens. I ett sådant perspektiv framstår den lönebidragsanställda som en resurs för att just kunna föra fram alternativa berättelser i en museimiljö. Deras roll som lekmän, men också som människor med en funktionsnedsättning, kan bidra med perspektiv som tidigare inte har hörsammats. Museet kan därmed nå och förstå grupper som det tidigare inte kommit i kontakt med eller representerat. Problemet är dock att lekmannaperspektivet befäster de narrativ som museer aktivt försöker att dekonstruera snarare än att ifrågasätta dem, och de kan på så sätt verka negativt ur demokratiseringssynpunkt (Rodéhn 2008).

På Jamtli går demokratisering av museet och Livslångt Lärande hand i hand. Ledningen har förstått den affirmativa roll som lärande kan spela för besökare och personal. Men om Jamtli på allvar vill använda Livslångt Lärande som metod och aktivt uppmuntra till lärande bland sina anställda måste museet ta ett större ansvar till att ge möjligheter, uppmuntra och efterfråga en effektiv läroprocess. Det är inte tillräckligt att nöja sig med att människor utbyter information under fikaraster eller med besökare. Jamtli behöver en vidare granskning av, och en arbetsplan för, hur Livslångt Lärande ansvarsfullt kan omsättas för att vara till nytta för individen, institutionen och samhället. Med en tydlig plan skulle Livslångt Lärande mycket väl kunna användas för att nå ett önskat resultat för rehabilitering och välmående, men som det ser ut nu är Livslångt Lärande ett vitt och otydligt begrepp och kan appliceras godtyckligt eftersom det saknar ett ramverk. Eftersom Livslångt Lärande inkorporerar alla former av social interaktion är det nästan omöjligt att inte påvisa att lärande har skett och därmed förutsätts också positiva resultat.

Jag ställer mig därför frågande till om Livslångt Lärande är en önskvärd metod eftersom det är en politisk jargong som i praktiken ekar ganska tom. Om museerna vill använda sig av Livslångt Lärande krävs det extra mycket av dem för att konkret påvisa vad för slags lärande de kan uppmuntra till och hur människor kan rehabiliteras. Ur demokratiseringssynpunkt är detta extra viktigt eftersom Nijhof (2005: 411) menar att Livslångt Lärande som teoretiskt begrepp och dess koppling till EU:s arbetsmarknadspolitik binder personen till en maktstruktur som kan resultera i marginalisering snarare än demokrati. Individens möjlighet till att lära sig beror därför på socioekonomisk differens men också på hur makt utövas inom institutionen i form av fördelning av resurser och prioritering av visst typ av lärande (t.ex. favorisering av teoretiskt lärande över praktiskt).

På frågan om lönebidragsanställningar och Livslångt Lärande kan leda till en demokratisering av museer är svaret både ja och nej. Både lönebidragsanställningar och Livslångt Lärande har i grunden demokratiska anspråk på det sättet att de vill skapa ett jämlikare samhälle genom att ge möjlighet till anställning och lärande. Men Livslångt Lärande är tyngt av politiska och ekonomiska implikationer som oftast bortses ifrån, vilket kan resultera i det motsatta. Lönebidragsanställningar ger möjligheter till att arbetshandikappade 
kan behålla ett aktivt arbetsliv samtidigt som de medverkar till att bevara, vårda och förmedla kulturarvet vid museer. Anställningen är kostnadseffektiv vilket resulterar i att museerna kan förmedla kulturarv trots små resurser. På så sätt kan museet vårda och förmedla kulturarvet och eventuellt komma att representera grupper som inte är synliga i kulturarvet. Även om museerna delvis är i behov av lönebidragsanställda för att kunna fortsätta sin verksamhet betyder inte att museer ska bli avstjälpningsplats för personer med problem. Museets professionella roll som kulturarvsinstitution måste bevaras om institutionerna ska kunna fortsätta att förmedla demokratiska värderingar och ett kvalitativt och inkluderande kulturarv.

Min förhoppning är att studien ska inspirera till ett ökat intresse för museer och arbetsmarknadsfrågor, för att utveckla museipedagogiska metoder som riktar sig till personer inom arbetsmarknadsåtgärder så att dessa ses som en tillgång och inte som en börda. I detta sammanhang kan museerna fungera som en verklig demokratisk tillgång. Museerna kan på så sätt utnyttja den specifika position och resurser de innehar som kulturarvsinstitutioner och fungera som rehabiliteringsplats, där hjälp till självhjälp genom kulturarv kan framhållas. Hur detta ska realiseras beror på ifrågavarande personers behov eftersom det kan röra sig om allt från psykiska, fysiska och sociala till intellektuella handikapp. En kulturarvsinstitution kan bidra med flera aspekter, t.ex. de kulturella och mjuka värden som genomsyrar institutionens arbete men också hantering av historiska föremål som kan frigöra personer från stress och skapa en känsla av kulturell och historisk kontinuitet. Eftersom museer inte är resultatinriktade på samma sätt som vinstdrivande arbetsplatser kan den arbetshandikap- pade ges möjlighet att arbeta efter sin förmåga. Museer skapar även tillfällen till social interaktion och gemenskap med kollegor och besökare och kan ge en känsla av sammanhang. Det finns dessutom stora möjligheter till kompetensutveckling då museet består av personal med olikartad och bred kompetens. Men det är viktigt att museet tar tillvara den arbetshandikappades intressen och kompetens så att denne kan utvecklas vid institutionen. På så sätt blir museet inte enbart en transitionsplats eller avstjälpningsplats utan kan göra en verklig skillnad.

\section{AvSLUTNING}

I den här texten har jag försökt belysa den politiska historien gällande lönebidrag och vilken politisk och ekonomisk vikt det har spelat för ett länsmuseum som Jamtli. Jag har även velat visa på hur nära knuten kulturarvspolitiken är till arbetsmarknadspolitik och handikappspolitik och vilken roll detta spelar för kulturarvsinstitutioner. Jag har även visat att Livslångt Lärande kan fungera både positivt och negativt. Positivt genom att det uppmärksammar att alla former av lärande kan bidra till en positiv förändring, negativt genom att det är styrt av maktanspråk som sätter gränser för lärandet. Men genom att använda begreppet Livslångt Lärande som metod kan man initiera diskussioner om social differentiering, hierarkier på arbetsplatsen och skapa en större förståelse för vad det innebär att vara arbetshandikappad på ett museum och i samhället i stort. Det behövs mer forskning om dessa frågor och den sociala sårbarhet som anställda med lönebidrag uppvisar, det avslöjar inte minst den låga svarsfrekvensen i denna studie. Därför menar jag att genom att förstå Livslångt Lärande som en metod snarare än en te- 
86 ori kan man börja upptäcka vilken resurs museet kan spela i samhället.

\section{FÖRFATTARENS TACK}

Jag skulle vilja utrycka mitt tack till mina informanter andra anställda vid Nordiskt Centrum för Kulturarvspedagogik, Jamtli och Landsarkivet Östersund för möjligheten att utföra studien. Jag vill även tacka Sofia Kling och Lisa Hagelin för värdefulla kommentarer.

\section{REFERENSER}

\section{Intervjuer}

Sten Rentzhog 2010-03-24

Sten Gauffin 2010-03-25

Henrik Zipsane 2010-02-25

Sara 2010-03-22

William 2010-03-09

Lisa 2010-03-10

Alexander 2010-03-19

Rupert 2010-03-03

\section{Arkivmaterial}

Länsmuseernas samarbetsråd: Utredning om Länsmuseernas ekonomi genomförda av länsmuseernas samarbetsråd på uppdrag av statens kulturråd. Stockholm. Jamtlis ämbetsarkiv. Sten Rentzhogs arkiv. Box: Utredning om länsmuseernas ekonomi: Östersund 1981.

Rentzhog, S.: Jämtlands läns museum. SR/Mb. 1979-01-18. Jamtlis ämbetsarkiv. F3ABB. Lönebidragstjänster, Beredskapstjänster 1945-2002: Östersund 1979.

Rentzhog, S.: Länsmuseernas verksamhetsnivå och resursbehov. Utredning av Sten Rentzhog, länsmuseernas samarbetsråd, på uppdrag av statens kulturråd. Jamtlis ämbetsarkiv. Sten Rentzhogs arkiv. Box: Länsmuseernas U-nivå och resursbehov: Östersund 1988.
Rentzhog, S.: Nedrustning av museer och arkiv. 1991-01-03. Jamtlis ämbetsarkiv. Sten Rentzhogs arkiv. Box: Lönebidrag 1988-1991: Östersund 1991.

Rentzhog, S.: Jämtlands Läns Museum: Lönebidragens betydelse för Länsmuseerna. 1997-05-04. Jamtlis ämbetsarkiv. F3ABB. Lönebidragstjänster, Beredskapstjänster 1945-2002: Östersund 1997.

Rentzhog, S. \& Hagberg, U.E.:1978-12-15. Föreningen Sveriges landsantikvarier. Till samtliga landsantikvarier. Jamtlis ämbetsarkiv. F3ABB. Lönebidragstjänster, Beredskapstjänster 1945-2002.

\section{Opublicerade dokument}

Budgetpropositionen. 1978. Budgetprop. 1978/79:73

Budgetpropositionen. 2010. Budgetprop. 2009/10: 1 EU: A memorandum on lifelong learning. Brussels 30.10.2000. SEC (2000) 1832, Bryssel 2000.

Jamtli: Jamtlis strategiplan 2011-2014. Arbetsdokument 2010-03-31. Östersund 2010.

\section{LITTERATUR}

Atkinson, P. \& Coffey, A.: "Analysing documentary realities". Qualitative research. Theory method and practice. Red: Silverman, D. Second Edition. Sage Publications: London, Thousand Oaks \& New Delhi 2004.

Barnett, R.: "Learning to work and working to learn". Understanding learning at work. Red: Boud, D. \& Garrick, J. Routledge: New York \& London 1999: 29-44.

Billette, S.: "Guided learning at work". Understanding learning at work. Red: Boud, D. \& Garrick, J. Routledge: New York \& London 1999: 151-164.

Billette, S.: "Workplace participatory practices. Conceptualizing workplaces as learning environ- 
ments". The workplace as a learning environment. Red: Moore, D.T. Emerald Group Publishing: Bradford 2004.

Boud, D. \& Garrick, J.: "Understanding of workplace learning". Understanding learning at work. Red: Boud, D. \& Garrick, J. Routledge: New York \& London 1999: 1-11.

Cox, J.: "Disabled persons: libertas: sounds, with visions and imaginations, for people with disabilities". Museum Management and Curatorship. No 9:3, 1990: 311-312.

Dehmel, A.: "Making a European Area of Lifelong Learning a reality? Some critical reflections on the European Union's Lifelong Learning policies". Comparative Education No 42:1, 2006: 49-62.

Denzig, N.K. \& Lincoln Y.: Handbook of qualitative research. Second Edition. Sage: Thousand Oaks, CA 2000.

Ellerström, P. E.: "Rutin och reflektion. Förutsättningar och hinder för lärande i dagligt arbete". Livslångt lärande. Red: Ellerström, P.E., Gustavsson, B. \& Larsson, S. Studentlitteratur: Lund 1996:142-179

Engelbrektsson, B.: Arkivarbetare vid Uppsala universitet 1934-1980. En studie av en arbetskraftsresurs ur ett systemperspektiv. Uppsala Universitet: Uppsala 1997.

Galla, A.: "Transformation in South Africa: a legacy challenged". Museum International. No 5:2, 2003: 38-43.

Garrick, J.: "The dominant discourse of learning at work". Understanding learning at work. Red: Boud, D. \& Garrick, J. Routledge: New York \& London 1999: 216-231.

Gustavsson, B.: "Att leva och lära livet ut - livslångt lärande ur ett integrativt perspektiv". Livslangt lärande. Red: Ellerström, P. E., Gustavsson, B. \& Larsson, S. Studentlitteratur: Lund 1996: 48-72.

Holmqvist, M.: "Erkänn ditt handikapp annars förlorar du a-kassan". Dagens Nyheter 2006-08-10. Jarvis, P.: "Globalisation, lifelong learning and the - learning society. Sociological perspectives". Lifelong learning and the learning society Vol 2. Routledge: London \& New York 2007.

Leymann, H.: Lönebidrag och mobbad. En svag grupps psykosociala arbetsvillkor i Sverige. Stockholms Universitet: Solna 1992.

Nijhof, W.J.: "Lifelong Learning as a European skill formation policy". Human Resources Development Review No 4:4, 2005: 401-417.

Oliver, P.: "The concept of lifelong learning". Lifelong and continuing education. What is a learning society. Red: Olivier, P. Ashgate Publishing: Burlington 1999.

Reddy, T.: "From Apartheid to democracy in South Africa: A reading of dominant discourses of democratic transition". The meaning of collective memory in South Africa. Red: Stolten, H.E. Nordiska Afrikainstitutet: Uppsala 2007.

Rix, J.: "Checking the list: Can model of Down syndrome help us explore the intellectual accessibility of heritage sites?" International Journal of Heritage Studies No 11:4, 2005: 341-356.

Rodéhn, C.: Lost in transformation. A critical study of two South African museums. Unpublished $\mathrm{PhD}$ dissertation. University of KwaZulu-Natal: Pietermaritzburg 2008.

Rodéhn, C.: Cultural heritage, democracy and the labour market. Nordiskt Centrum för Kulturarvspedagogik: Östersund 2010.

Rodéhn, C.: "Democracy, lifelong learning and labour market policies". Heritage, regional development and social cohesion. Red: Kearns, P., Kling, S., Wistman, C. Jamtli förlag: Östersund 2011: 112-129.

Sandell, R. \& Dodd, J.: Re-Presenting disability: activism and agency in the museum. Routledge: New York \& London 2010.

Simpson, M.: "Revealing and concealing: aboriginal Australia". New museum theory and practice. An introduction. Red: Marstine, J. Blackwell: Oxford 2006. 
Sivesind, J.: "Sheltered employment to help shoulder responsibilities." Museum International 33:3, 1981: 146-150.

SOU: "Aktivt lönebidrag. Ett effektivare stöd för arbetshandikappade. Delbetänkande av LOSAMutredningen". Arbetsmarknadsdepartementet. SOU 1997:5. Stockholm 1997.

SOU: "ArbetsKraft. Betänkande från lönebidragsutredningen". SOU 2003: 95. Stockholm 2003.

SOU: "Betänkande av kulturutredningen". SOU 2009:16. Stockholm 2009a.

SOU: "Betänkande av kulturutredningen. Förnyelseprogram". SOU 2009:16. Stockholm 2009b.

SOU: "Betänkande av kulturutredningen. Kulturpolitikens arkitektur". SOU 2009:16. Stockholm 2009c.

Svensk Författningssamling (SFS): "Lag om vissa åtgärder för att främja sysselsättningen av äldre arbetstagare på den öppna marknaden”. No 1-422. Liber Allmänna förlaget: Stockholm 1971: 202.

Svensk Författningssamling (SFS): "Lag om vissa anställningsfrämjande åtgärder”. No 1-366. Liber Allmänna förlaget: Stockholm 1974: 13.

Svensk Författningssamling (SFS): "Lag om anställningsskydd". No 1-366. Liber Allmänna förlaget: Stockholm 1974: 12.

Svensk Författningssamling (SFS): "Förordning om lönebidrag". No 1-767. Liber Allmänna förlaget: Stockholm 1991: 333.

Trygged, S.: Arbetslös och medellös en studie av beredskapsarbete i Stockholm. Stockholms universitet: Stockholm 1996.

Zipsane, H.: "Local and regional development through heritage learning". www.obs-pascal.com 2007. (Hämtat 2010-09-13)

Zipsane, H.: "Lifelong learning through heritage and art", The Routledge international handbook of lifelong learning. Red: Jarvis, P. Routledge: London \& New York, 2008: 173-182.
Cecilia Rodéhn är anställd som forskare på Institutionen for ABM, Uppsala Universitet. Hon disputerade 2009 vid University of KwaZuluNatal i ämnet Museum Studies. Avhandlingen Lost in transformation. A critical study of two South African museums, behandlade museer och kulturarv i övergaingen frän apartheid till demokrati. Rodéhn har arbetat på Nordiskt Centrum för Kulturarvspedagogik och som museipedagog på ett antal svenska museer.

\section{${ }^{*}$ Cecilia Rodéhn}

Address: Institutionen för ABM, Uppsala Universitet

Box 625,

SE-75126 Uppsala

\section{E-mail: Cecilia.rodehn@abm.uu.se Cecilia_rodehn@hotmail.com}

